\title{
CHANGING SOCIO-ECONOMIC CONDITIONS AND THE NEED FOR NEW DEVELOPMENT POLICIES IN THE SOUTH
}

\author{
David Mulkey*
}

\author{
Introduction
}

After emerging from its agarian past somewhat later than the rest of the nation, there is little doubt that the South today would be described as successful from a development standpoint. The area has grown in an absolute sense and relative to the nation as a whole, and as Clay and Stuart note in a recent study, is radically different from the South of relatively recent times. The key question is whether or not past growth rates can be maintained in the future. Or, in other words, does the future call for different development strategies than the past.

To set the stage for this discussion, this paper will briefly review trends in population and employment growth in the South at the regional and state level and compare these trends to the U.S. as a whole. After this review the paper will look in more detail at factors underlying the growth of manufacturing employment in the central states of the South and discuss one area where a new development strategy or set of strategies appears necessary.

\section{The South: An Overview}

The sixteen states and the District of Columbia comprising the South Atlantic, the East South Central and the West South Central census divisions in 1980 contained over 33 percent of the nation's population, (Table 1). Further, while the national population growth rate slowed significantly over the 1970-1980 period, each of the three southern census divisions grew faster over the 1970-1980 period than over previous ten-year census intervals. Also, with the exceptions of Delaware, Maryland, and the District of Columbia, each state within the region had population growth rates which exceeded the national growth rate (Table 2). Of those states exceeding the national population growth rate over the 1970-1980 period, only three, Florida, Texas, and Virginia, grew faster than the nation over the 1960-1970 period.

Southern population growth has also been paralleled by increases in employment. As noted, the south in 1980 contained slightly over 33 percent of the nation's population, and in 1981 the region represented almost the same percentage (32.56) of total U.S. employment. The region also contained slightly over 30 percent of the nation's manufacturing employment (Table 3 ).

Looking at the distribution of employment by type in the southern states (Table 4) reveals the importance of manufacturing employment in the south. Nine states have a concentration of employment in manufacturing which equals or in many cases significantly exceeds, the percentage of employment in manufacturing for the United States as a whole. With the exception of Delaware, this represents a group of eight contigous states (North Carolina, South Carolina, Georgia, Kentucky, Tennessee, Alabama, Mississippi and Arkansas) centrally located in the southern region. These eight states generally have less than national average concentrations of employment in trade and services while six of the eight states exceed national concentrations for government employment.

*Florida Experiment Stations Journal Series Number 5683. Associate Professor, Department of Food and Resourc Economics, University of Florida, Gainesville, Florida. 
TABLE 1

Population, Southern States and United States, selected years, 1940-80. (Thousands)

\begin{tabular}{lccccc}
\hline \multicolumn{1}{c}{ State } & 1940 & 1950 & 1960 & 1970 & 1980 \\
\hline South Atlantic & $17,823(13.48)^{*}$ & $21,182(13.99)$ & $25,972(14.48)$ & $30,678(15.08)$ & $36,959(16.31)$ \\
Delaware & 267 & 318 & 446 & 548 & 594 \\
Maryland & 1,821 & 2,343 & 3,101 & 3,924 & 4,217 \\
District of & & & & & \\
Columbia & 663 & 802 & 764 & 757 & 638 \\
Virginia & 2,678 & 3,319 & 3,967 & 4,651 & 5,347 \\
West Virginia & 1,902 & 2,006 & 1,860 & 1,744 & 1,950 \\
North Carolina & 3,572 & 4,062 & 4,556 & 5,084 & 5,882 \\
South Carolina & 1,900 & 2,117 & 2,383 & 2,591 & 3,122 \\
Georgia & 3,124 & 3,445 & 3,943 & 4,588 & 5,463 \\
Florida & 1,897 & 2,771 & 4,952 & 6,791 & 9,746 \\
East So. Central & $10,778(8.15)$ & $11,477(7.58)$ & $12,050(6.72)$ & $12,808(6.30)$ & $14,666(6.47)$ \\
Kentucky & 2,846 & 2,945 & 3,038 & 3,221 & 3,661 \\
Tennessee & 2,916 & 3,292 & 3,567 & 3,926 & 4,951 \\
Alabama & 2,833 & 3,062 & 3,267 & 3,444 & 3,894 \\
Mississippi & 2,184 & 2,179 & 2,178 & 2,217 & 2,521 \\
West So. Central & $13,085(9.90)$ & $14,538(9.60)$ & $18,951(10.57)$ & $19,326(9.51)$ & $23,747(10.48)$ \\
Arkansas & 1,949 & 1,910 & 1,786 & 1,923 & 2,286 \\
Louisiana & 2,364 & 2,684 & 3,257 & 3,645 & 4,206 \\
Oklahoma & 2,336 & 2,233 & 2,328 & 2,559 & 3,025 \\
Texas & 6,415 & 7,711 & 9,580 & 11,229 & 14,220 \\
Southern Region & $41,686(31.54)$ & $47,197(31.19)$ & $56,973(31.17)$ & $62,812(30.89)$ & $75,372(33.27)$ \\
United States & 132,165 & 151,326 & 179,323 & 203,302 & 226,564 \\
\hline
\end{tabular}

Source: U.S. Department of Commerce, Bureau of the Census, Statistical Abstract of the United States, 1982-83.

*Numbers in parentheses are percentages of the United States total.

TABLE 2

Percentage Change in Population, Southern States and United States, Selected Years, 1940-1980

\begin{tabular}{lrrrr}
\hline \multicolumn{1}{r}{ State } & $1940-50$ & $1950-60$ & $1960-70$ & $1970-80$ \\
\hline & 18.8 & 22.6 & 18.1 & 20.4 \\
Delaware & 19.1 & 40.3 & 22.9 & 8.4 \\
Maryland & 28.6 & 32.2 & 26.5 & 7.4 \\
District of & & & & \\
$\quad$ Columbia & 20.9 & -4.7 & -0.9 & -15.7 \\
Virginia & 23.9 & 19.5 & 17.2 & 14.9 \\
West Virginia & 5.4 & -7.2 & -6.2 & 11.8 \\
North Carolina & 13.7 & 12.1 & 11.5 & 15.6 \\
South Carolina & 16.6 & 12.5 & 8.7 & 20.4 \\
Georgia & 10.2 & 14.4 & 16.3 & 19.0 \\
Florida & 46.0 & 78.7 & 37.1 & 43.5
\end{tabular}


TABLE 2 (continued)

Percentage Change in Population, Southern States and United States, Selected Years, 1940-1980

\begin{tabular}{lrrrr}
\hline \multicolumn{1}{c}{ State } & $1940-50$ & $1950-60$ & $1960-70$ & $1970-80$ \\
\hline East So. Central & 6.4 & 4.9 & 6.2 & 14.5 \\
Kentucky & 3.4 & 3.1 & 6.0 & 13.6 \\
Tennessee & 12.8 & 8.3 & 10.0 & 16.9 \\
Alabama & 8.0 & -6.6 & 5.4 & 13.0 \\
Mississippi & -2 & -.04 & 1.7 & 13.7 \\
West So. Central & 11.2 & 16.5 & 14.0 & 22.8 \\
Arkansas & -1.9 & -6.4 & 7.6 & 18.8 \\
Louisiana & 13.5 & 21.3 & 11.9 & 15.3 \\
Oklahoma & -4.4 & 4.2 & 9.9 & 18.2 \\
Texas & 20.2 & 24.2 & 17.2 & 26.7 \\
United States & 14.4 & 18.5 & 13.3 & 9.9 \\
\hline
\end{tabular}

Source: Calculated from Table 1.

TABLE 3

Employment by Type, Southern States and United States, 1981. (Thousands)

\begin{tabular}{|c|c|c|c|c|c|c|c|c|}
\hline State & Total & $\begin{array}{c}\text { Manufac- } \\
\text { turing }\end{array}$ & $\begin{array}{c}\text { Whole- } \\
\text { sale } \\
\text { and } \\
\text { retail } \\
\text { trade }\end{array}$ & $\begin{array}{c}\text { Govern- } \\
\text { ment }\end{array}$ & $\begin{array}{r}\text { Serv- } \\
\text { ices }\end{array}$ & $\begin{array}{l}\text { Trans- } \\
\text { portation, } \\
\text { public } \\
\text { utilities }\end{array}$ & $\begin{array}{l}\text { Fi- } \\
\text { nance, } \\
\text { insur- } \\
\text { ance, } \\
\text { real } \\
\text { estate }\end{array}$ & $\begin{array}{c}\text { Contract } \\
\text { con- } \\
\text { struction }\end{array}$ \\
\hline South Atlantic & 14,853 & 3,036 & 3,310 & 3,073 & 2,703 & 825 & 802 & 836 \\
\hline Delaware & 259 & 71 & 56 & 44 & 49 & 12 & 13 & 13 \\
\hline Maryland & 1,710 & 231 & 406 & 422 & 377 & 86 & 93 & 96 \\
\hline \multicolumn{9}{|l|}{ District of } \\
\hline Columbia & 612 & 15 & 64 & 275 & 187 & 26 & 34 & 12 \\
\hline Virginia & 2,160 & 412 & 463 & 510 & 416 & 117 & 106 & 116 \\
\hline W. Virginia & 624 & 111 & 131 & 131 & 101 & 42 & 22 & 28 \\
\hline N. Carolina & 2,386 & 817 & 473 & 409 & 352 & 117 & 98 & 115 \\
\hline S. Carolina & 1,197 & 392 & 231 & 234 & (NA) & 54 & 50 & 71 \\
\hline Georgia & 2,183 & 520 & 503 & 434 & 359 & 144 & 114 & 102 \\
\hline Florida & 3,722 & 467 & 983 & 615 & 863 & 229 & 272 & 283 \\
\hline East So. Central & 5,109 & 1,362 & 1,066 & 1,016 & 853 & 265 & 222 & 236 \\
\hline Kentucky & 1,193 & 272 & 258 & 227 & 215 & 67 & 52 & 51 \\
\hline Tennessee & 1,746 & 507 & 373 & 309 & 307 & 86 & 78 & 77 \\
\hline Alabama & 1,350 & 362 & 271 & 293 & 211 & 72 & 59 & 66 \\
\hline Mississippi & 821 & 221 & 163 & 187 & 121 & 41 & 33 & 42 \\
\hline
\end{tabular}


TABLE 3 (continued)

Employment by Type, Southern States and United States, 1981. (Thousands)

\begin{tabular}{|c|c|c|c|c|c|c|c|c|}
\hline State & Total & $\begin{array}{c}\text { Manufac- } \\
\text { turing }\end{array}$ & $\begin{array}{c}\text { Whole- } \\
\text { sale } \\
\text { and } \\
\text { retail } \\
\text { trade }\end{array}$ & $\begin{array}{c}\text { Govern- } \\
\text { ment }\end{array}$ & $\begin{array}{l}\text { Serv- } \\
\text { ices }\end{array}$ & $\begin{array}{l}\text { Trans- } \\
\text { portation, } \\
\text { public } \\
\text { utilities }\end{array}$ & $\begin{array}{c}\text { Fi- } \\
\text { nance, } \\
\text { insur- } \\
\text { ance, } \\
\text { real } \\
\text { estate }\end{array}$ & $\begin{array}{c}\text { Contract } \\
\text { con- } \\
\text { struction }\end{array}$ \\
\hline West So. Central & 9,705 & 1,737 & 2,314 & 1,676 & 1,692 & 628 & 512 & 658 \\
\hline Arkansas & 740 & 210 & 160 & 138 & 117 & 43 & 32 & 34 \\
\hline Louisiana & 1,628 & 220 & 369 & 306 & 288 & 132 & 75 & 139 \\
\hline Oklahoma & 1,193 & 199 & 278 & 237 & 202 & 69 & 59 & 54 \\
\hline Texas & 6,144 & 1,107 & 1,506 & 995 & 1,085 & 384 & 347 & 431 \\
\hline United States & 91,105 & 20,173 & 20,551 & 16,024 & 18,592 & 5,157 & 5,301 & 4,176 \\
\hline
\end{tabular}

Source: U.S. Department of Commerce, Bureau of the Census, Statistical Abstract of the United States, $1982-83$.

TABLE 4

Percentage Distribution of Employment, Southern States and United States, 1981

\begin{tabular}{|c|c|c|c|c|c|c|c|}
\hline State & $\begin{array}{c}\text { Manufac- } \\
\text { turing }\end{array}$ & $\begin{array}{c}\text { Whole- } \\
\text { sale } \\
\text { and } \\
\text { retail } \\
\text { trade }\end{array}$ & $\begin{array}{c}\text { Govern- } \\
\text { ment }\end{array}$ & $\begin{array}{r}\text { Serv- } \\
\text { ices }\end{array}$ & $\begin{array}{l}\text { Trans- } \\
\text { portation, } \\
\text { public } \\
\text { utilities }\end{array}$ & $\begin{array}{l}\text { Fi- } \\
\text { nance, } \\
\text { insur- } \\
\text { ance, } \\
\text { real } \\
\text { estate }\end{array}$ & $\begin{array}{c}\text { Contract } \\
\text { con- } \\
\text { struction }\end{array}$ \\
\hline South Atlantic & 20.4 & 22.3 & 20.7 & 18.2 & 5.6 & 5.4 & 5.6 \\
\hline Delaware & 27.4 & 21.6 & 17.0 & 18.9 & 4.6 & 5.0 & 5.0 \\
\hline Maryland & 13.5 & 23.7 & 24.7 & 22.0 & 5.0 & & 5.4 \\
\hline \multicolumn{8}{|l|}{ District of } \\
\hline Columbia & 2.4 & 10.4 & 44.9 & 30.6 & 4.2 & 5.6 & 2.0 \\
\hline Virginia & 19.1 & 21.4 & 23.6 & 19.3 & 5.4 & 4.9 & 5.4 \\
\hline W. Virginia & 17.8 & 21.0 & 21.0 & 16.2 & 6.7 & 3.5 & 4.5 \\
\hline N. Carolina & 34.2 & 19.8 & 17.1 & 14.8 & 4.9 & 4.1 & 4.8 \\
\hline S. Carolina & 32.7 & 19.3 & 19.5 & (NA) & 4.5 & 4.2 & 5.9 \\
\hline Georgia & 23.8 & 23.0 & 19.9 & 16.4 & 6.6 & 5.2 & 4.7 \\
\hline Florida & 12.5 & 26.4 & 16.5 & 23.2 & 6.2 & 7.3 & 7.6 \\
\hline East So. Central & 26.7 & 20.9 & 19.9 & 16.7 & 5.2 & 4.3 & 4.6 \\
\hline Kentucky & 22.8 & 21.6 & 19.0 & 18.0 & 5.6 & 4.4 & 4.3 \\
\hline Tennessee & 29.0 & 21.4 & 17.7 & 17.6 & 4.9 & 4.5 & 4.4 \\
\hline Alabama & 26.8 & 20.1 & 21.7 & 15.6 & 5.3 & 4.4 & 4.9 \\
\hline Mississippi & 26.9 & 19.8 & 22.8 & 14.7 & 5.0 & 4.0 & 5.1 \\
\hline
\end{tabular}


Changing Socio-Economic Conditions

TABLE 4 (continued)

Percentage Distribution of Employment, Southern States and United States, 1981

\begin{tabular}{llllllll}
\hline West So. Central & 17.9 & 23.8 & 17.3 & 17.4 & 6.5 & 5.3 & 6.8 \\
Arkansas & 28.4 & 21.6 & 18.6 & 15.8 & 5.8 & 4.3 & 4.6 \\
Louisiana & 13.5 & 22.7 & 18.8 & 17.7 & 8.1 & 4.6 & 8.5 \\
Oklahoma & 16.7 & 23.3 & 19.8 & 16.9 & 5.8 & 4.9 & 4.5 \\
Texas & 18.0 & 24.5 & 16.2 & 17.7 & 6.3 & 5.6 & 7.0 \\
United States & 22.1 & 22.6 & 17.6 & 20.4 & 5.7 & 5.8 & 4.6 \\
\hline
\end{tabular}

Source: Calculated from Table 4.

Comparing 1969 to 1981 reveals some insights into changes in employment in the South relative to the nation. Over this period, total U.S. employment increased by 29.9 percent while employment increased by 44.8 percent, 35.3 percent, and 68.3 percent, respectively, in the South Atlantic, the East South Central, and the West South Central divisions. With the exceptions of Delaware, the District of Columbia and West Virginia, each state in the Southern region increased employment at a rate faster than the national average over the 1969-1981 period (Tables 5, 6, and 7).

In the nation, with the exception of manufacturing, all categories of employment showed significant increases over the 1969-1981 period with each Southern region and each state within the three regions exceeding the national growth rate. There is, however, a major distinction between the region and the nation in manufacturing employment changes. Over the 1969-1981 period national manufacturing employment increased only slightly $(0.25$ percent $)$. In the South manufacturing employment increased 11.0 percent in the South Atlantic Region, 15.4 percent in the East South Central and 48.9 percent in the West South Central. Manufacturing employment decreased in Delaware, Maryland, the District of Columbia and West Virginia. All other Southern states showed increases ranging from 9.0 percent in Georgia up to more than $\mathbf{4 0}$ percent in Florida, Oklahoma and Texas.

To be sure, this brief review of Southern population and employment growth has been cursory and based only on aggregate data. However, the conclusion with respect to development in the region as a whole seems beyond question. There are, however, some distinct differences among states or groups of states in the region.

The rapidly growing states of Florida and Texas immediately stand out from the others. For each major category of employment (manufacturing, trade and services) these two states accounted for more than 40 percent of new employment in the region over the 1969-1981 period. Oklahoma and Louisiana could also be included in this group. Each of these four states has relatively low concentrations of employment in manufacturing, and total employment (including manufacturing employment) grew rapidly over the 1969-1981 period.

At the other end of the Southern region, the states of Delaware, Maryland and West Virginia stand out for different reasons. Increases in population in Delaware and Maryland were below the national average over the 1970-1980 period while the population growth rate in West Virginia exceeded the national average by only two percentage points. Further, each of these states had declines in manufacturing employment over the 1969-1981 period, and total employment growth was generally slower than for other states in the region.

In this same geographic region Virginia also appears different from other states. The concentration of employment in manufacturing is lower but showed a significant increase over the 1969-1981 period. Total employment grew rapidly over the same period, especially in the services sector. In a sense Virginia appears more similar to the rapidly growing states than to her sister states on either side.

The remaining states in the region (North Carolina, South Carolina, Georgia, Kentucky, Tennessee, Alabama, Mississippi and Arkansas) are similar. All have relatively high concentrations of employment in manufacturing, and all increased both total and manufacturing employment over the 1969-1981 period. 
Table 5

Employment by Type, Southern States and United States, 1969. (Thousands)

\begin{tabular}{|c|c|c|c|c|c|c|c|c|}
\hline State & Total & $\begin{array}{c}\text { Manufac- } \\
\text { turing }\end{array}$ & $\begin{array}{c}\text { Whole- } \\
\text { sale } \\
\text { and } \\
\text { retail } \\
\text { trade }\end{array}$ & $\begin{array}{c}\text { Govern- } \\
\text { ment }\end{array}$ & $\begin{array}{r}\text { Serv- } \\
\text { ices }\end{array}$ & $\begin{array}{l}\text { Trans- } \\
\text { portation, } \\
\text { public } \\
\text { utilities }\end{array}$ & $\begin{array}{c}\text { Fi- } \\
\text { nance, } \\
\text { insur- } \\
\text { ance, } \\
\text { real } \\
\text { estate }\end{array}$ & $\begin{array}{c}\text { Contract } \\
\text { con- } \\
\text { struction }\end{array}$ \\
\hline South Atlantic & 10,261 & 2,733 & 2,112 & 2,081 & 1,510 & 1,015 & 478 & 629 \\
\hline Delaware & 208 & 73 & 43 & 30 & 29 & 11 & 9 & 13 \\
\hline Maryland & 1,277 & 281 & 293 & 245 & 227 & 79 & 66 & 85 \\
\hline \multicolumn{9}{|l|}{ District of } \\
\hline Columbia & 681 & 20 & 85 & 360 & 134 & 31 & 32 & 18 \\
\hline Virginia & 1,434 & 370 & 295 & 293 & 208 & 95 & 65 & 94 \\
\hline W. Virginia & 513 & 131 & 93 & 95 & 64 & 41 & 15 & 26 \\
\hline N. Carolina & 1,735 & 713 & 309 & 254 & 201 & 90 & 67 & 97 \\
\hline S. Carolina & 812 & 339 & 135 & 140 & 83 & 35 & 28 & 49 \\
\hline Georgia & 1,522 & 477 & 320 & 285 & 177 & 103 & 72 & 82 \\
\hline Florida & 2,079 & 329 & 539 & 379 & 387 & 148 & 124 & 165 \\
\hline East So. Central & 3,775 & 1,223 & 725 & 715 & 492 & 212 & 152 & 210 \\
\hline Kentucky & 895 & 247 & 181 & 167 & 123 & 60 & 35 & 55 \\
\hline Tennessee & 1,312 & 470 & 255 & 214 & 176 & 66 & 56 & 68 \\
\hline Alabama & 999 & 324 & 185 & 205 & 127 & 56 & 41 & 54 \\
\hline Mississippi & 569 & 182 & 104 & 129 & 66 & 30 & 20 & 33 \\
\hline West So. Central & 5,941 & 1,228 & 1,351 & 1,144 & 916 & 430 & 290 & 382 \\
\hline Arkansas & 532 & 168 & 105 & 101 & 72 & 32 & 21 & 30 \\
\hline Louisiana & 1,044 & 181 & 228 & 207 & 151 & 93 & 49 & 83 \\
\hline Oklahoma & 754 & 130 & 165 & 185 & 108 & 53 & 36 & 37 \\
\hline Texas & 3,611 & 749 & 853 & 651 & 585 & 252 & 184 & 232 \\
\hline United States & 70,141 & 20,121 & 14,644 & 12,227 & 11,103 & 4,448 & 3,559 & 3,411 \\
\hline
\end{tabular}

Source: U.S. Department of Commerce, Bureau of the Census, Statistical Abstract of the United States, 1970.

Rates of employment increase, however, were generally less than in the rapidly growing states but above those for the nation as a whole. As noted earlier these states represent a contiguous belt of manufacturing states located in the central part of the Southern region.

\section{A Need for a New Development Strategy}

As is evident from the review here and from more detailed studies such as the one by Clay and Stuart, the South is not a homogenous region. At least three distinct groups of states are seen, the rapidly growing states of Florida and Texas along with the similar states of Louisiana, Oklahoma, and perhaps Virginia, the group of states consisting of Delaware, Maryland and West Virginia with slower growth and declining manufacturing employment, and the remaining group of centrally located Southern states with relatively high concentrations of manufacturing employment.

It is in this latter group of manufacturing states that the need for a new development strategy appears most obvious. The region cannot continue to grow rapidly by continuing to attract employment in a 
Table 6

Changes in Employment, by Type, Southern States and United States, 1969-81. (Thousands)

\begin{tabular}{|c|c|c|c|c|c|c|c|c|}
\hline State & Total & $\begin{array}{c}\text { Manufac- } \\
\text { turing }\end{array}$ & $\begin{array}{c}\text { Whole- } \\
\text { sale } \\
\text { and } \\
\text { retail } \\
\text { trade }\end{array}$ & $\begin{array}{c}\text { Govern- } \\
\text { ment }\end{array}$ & $\begin{array}{l}\text { Serv- } \\
\text { ices }\end{array}$ & $\begin{array}{l}\text { Trans- } \\
\text { portation, } \\
\text { public } \\
\text { utilities }\end{array}$ & $\begin{array}{l}\text { Fi- } \\
\text { nance, } \\
\text { insur- } \\
\text { ance, } \\
\text { real } \\
\text { estate }\end{array}$ & $\begin{array}{c}\text { Contract } \\
\text { con- } \\
\text { struction }\end{array}$ \\
\hline South Atlantic & 4,592 & 303 & 1,198 & 1,140 & 1,194 & 194 & 324 & 207 \\
\hline Delaware & 51 & -2 & 13 & 14 & 20 & 1 & 4 & 0 \\
\hline Maryland & 433 & -50 & 113 & 177 & 150 & 7 & 27 & 11 \\
\hline \multicolumn{9}{|l|}{ District of } \\
\hline Columbia & 69 & -5 & 21 & 62 & 53 & -5 & 2 & -6 \\
\hline Virginia & 726 & 42 & 168 & 217 & 208 & 22 & 41 & 22 \\
\hline W. Virginia & 111 & -20 & 38 & 36 & 37 & 1 & 7 & 2 \\
\hline N. Carolina & 651 & 104 & 164 & 155 & 151 & 27 & 31 & 18 \\
\hline S. Carolina & 385 & 53 & 96 & 94 & -83 & 19 & 22 & 22 \\
\hline Georgia & 661 & 43 & 183 & 149 & 182 & 41 & 42 & 20 \\
\hline Florida & 1,643 & 138 & 444 & 236 & 476 & 81 & 148 & 118 \\
\hline East So. Central & 1,335 & 189 & 340 & 301 & 362 & 54 & 70 & 26 \\
\hline Kentucky & 298 & 25 & 77 & 60 & 92 & 7 & 17 & -4 \\
\hline Tennessee & 434 & 87 & 118 & 95 & 131 & 20 & 22 & 9 \\
\hline Alabama & 351 & 38 & 86 & 88 & 84 & 16 & 18 & 12 \\
\hline Mississippi & 252 & 39 & 59 & 58 & 55 & 11 & 13 & 9 \\
\hline West So. Central & 3,764 & 601 & 962 & 532 & 776 & 198 & 212 & 276 \\
\hline Arkansas & 208 & 135 & 55 & 37 & 45 & 11 & 0 & 4 \\
\hline Louisiana & 584 & 39 & 141 & 99 & 137 & 39 & 26 & 56 \\
\hline Oklahoma & 439 & 69 & 113 & 52 & 94 & 16 & 23 & 17 \\
\hline Texas & 2,533 & 358 & 653 & 344 & 500 & 132 & 163 & 199 \\
\hline United States & 20,964 & 52 & 5,907 & 3,797 & 7,489 & 709 & 1,742 & 765 \\
\hline
\end{tabular}

Source: Calculated from Tables 3 and 5.

sector that is slow-growing or declining in the nation as a whole. To substantiate this point it is useful to look at some of the factors underlying the growth of the region in the past.

How does one explain the growth in manufacturing employment in the South? There seems to be little hard evidence of any overt strategy sufficient to swing the development balance from the Northeast or Midwest. One can point to the regional development programs of the 1960s (Newman) or to the activities of state and local development groups in the region, but there is no strong evidence of regional impact. In fact, most studies of various development incentives conclude that they have minimal effects on interregional location decisions of manufacturing firms (Mulkey and Dillman, Miller).

For those who subscribe to the "Sunbelt" philosophy and see capital fleeing the decaying Northeast and Midwest to higher returns in the South, the neo-classical model or the commulative causation model of regional growth offer attractive alternatives for explaining Southern growth (Richardson). In the former differential regional growth rates represent the market's attempt to equalize rates of return to factors of production across space while, in the latter, growth in the region stimulates productivity 
Table 7

Percentage change, by Type, Southern States and United States, 1969-81. (Thousands)

\begin{tabular}{|c|c|c|c|c|c|c|c|c|}
\hline State & Total & $\begin{array}{l}\text { Manufac- } \\
\text { turing }\end{array}$ & $\begin{array}{c}\text { Whole- } \\
\text { sale } \\
\text { and } \\
\text { retail } \\
\text { trade }\end{array}$ & $\begin{array}{c}\text { Govern- } \\
\text { ment }\end{array}$ & $\begin{array}{r}\text { Serv- } \\
\text { ices }\end{array}$ & $\begin{array}{l}\text { Trans- } \\
\text { portation, } \\
\text { public } \\
\text { utilities }\end{array}$ & $\begin{array}{c}\text { Fi- } \\
\text { nance, } \\
\text { insur- } \\
\text { ance, } \\
\text { real } \\
\text { estate }\end{array}$ & $\begin{array}{c}\text { Contract } \\
\text { con- } \\
\text { struction }\end{array}$ \\
\hline South Atlantic & 44.8 & 11.0 & 56.7 & 54.7 & 79.0 & 19.1 & 67.7 & 32.9 \\
\hline Delaware & 24.5 & $-\quad .02$ & 30.2 & 46.6 & 68.9 & .09 & 44.4 & 0 \\
\hline Maryland & 33.9 & -17.7 & 38.5 & 72.2 & 66.0 & .08 & 40.9 & 12.9 \\
\hline \multicolumn{9}{|l|}{ District of } \\
\hline Columbia & -10.1 & $-\quad .25$ & -24.7 & 17.2 & 39.5 & 16.1 & .06 & -33.3 \\
\hline Virginia & 50.6 & 11.3 & 56.9 & 74.0 & 100.0 & 23.1 & 63.0 & 23.4 \\
\hline W. Virginia & 21.6 & -15.2 & 40.8 & 37.8 & 57.8 & .02 & 46.6 & 7.6 \\
\hline N. Carolina & 37.5 & 14.5 & 53.0 & 61.0 & 75.1 & 3.0 & 46.2 & 18.5 \\
\hline S. Carolina & 47.4 & 15.6 & 71.1 & 67.1 & & 54.2 & 78.5 & 44.8 \\
\hline Georgia & 43.4 & 9.0 & 57.1 & 52.2 & 102.8 & 39.8 & 58.3 & 24.3 \\
\hline Florida & 79.0 & 41.9 & 82.3 & 62.2 & 122.0 & 54.7 & 38.7 & 71.5 \\
\hline East So. Central & 35.3 & 15.4 & 46.8 & 42.0 & 73.5 & 25.4 & 46.0 & 12.3 \\
\hline Kentucky & 33.2 & 10.1 & 42.5 & 35.9 & 74.7 & 11.6 & 48.5 & -7.2 \\
\hline Tennessee & 33.0 & 34.0 & 46.2 & 44.3 & 74.4 & 30.3 & 39.2 & 13.2 \\
\hline Alabama & 35.1 & 11.7 & 46.4 & 42.9 & 66.1 & 28.5 & 43.9 & 22.2 \\
\hline Mississippi & 44.2 & 21.4 & 56.7 & 44.9 & 83.3 & 36.6 & 65.0 & 27.2 \\
\hline West So. Central & 63.3 & 48.9 & 71.2 & 46.5 & 84.7 & 46.0 & 73.1 & 72.2 \\
\hline Arkansas & 39.0 & 25.0 & 52.3 & 36.6 & 62.5 & 34.3 & 0 & 13.3 \\
\hline Louisiana & 55.9 & 21.5 & 61.8 & 47.8 & 90.7 & 41.9 & 53.0 & 67.4 \\
\hline Oklahoma & 58.2 & 53.0 & 68.4 & 28.1 & 87.0 & 30.1 & 63.8 & 45.9 \\
\hline Texas & 70.1 & 47.7 & 76.5 & 52.8 & 85.4 & 52.3 & 88.5 & 85.7 \\
\hline United States & 29.8 & .002 & 40.3 & 31.0 & 67.4 & 15.9 & 48.9 & 22.4 \\
\hline
\end{tabular}

Source: Calculated from Tables 4 and 6.

growth which, in turn, leads to more growth. Neither approach, however, is consistent with the findings of a recent study of regional productivity growth in U.S. manufacturing. Hulten and Schwab conclude that the main source of variation between regions in output growth over the 1951-1978 period was the increased use of inputs in the rapidly growing regions, not increased productivity in the regic/s.

An alternative explanation of manufacturing employment growth in the South consistent with the findings of Hulten and Schwab is Hansen's treatment of the concept of spatial-industrial filtering and the related product life cycle. In this approach as products reach the mature stage of their life cycle, production is associated with an increasing use of capital, a decreasing use of skilled, expensive labor, and an associated geographic relocation of production.

In support of this approach Hansen cites the growth of manufacturing employment in non-metropolitan areas (lower-skilled, lower-wage places) and evidence that a large part of new manufacturing employment is in branch plants of national firms. The product cycle approach is also supported by findings of a study of business climates and industrial performance by Fisher and Hanink. They found above national 
average growth rates in manufacturing employment associated with a set of factors which translate to lower-skill and lower-wage labor.

If the product cycle approach is accepted as explanatory of growth in Southern manufacturing employment, then the Southern development strategy of the past has been an implicit one centered on relatively cheap labor. Again, the major implication is, as Hansen notes, the process cannot continue forever. Eventually, shifts of manufacturing employment to the region can no longer offset national slow growth or delcine of the manufacturing sector. Further, as wages in the region increase, manufacturing jobs may relocate to other countries with even lower wages.

The possibility then looms that the South at some point may experience structural changes similar to those of the Northeast and Midwest. In fact, a county level study of Southern growth by Clay and Stuart indicates that the process may be starting. They note that of those counties in the South experiencing slow growth or losses in population, many are dependent on low wage manufacturing and tend to be older industrial areas of the Carolinas, Georgia and Alabama with manufacturing concentrated in textiles.

\section{Some Observations on Policy Alternatives}

If then, as suggested here, the future of the South is not in the continued development of manufacturing industry based on relatively lower wages, what are the implications for development policy alternatives? Some observations are offered with respect to continued development activity in the manufacturing area and investments in human capital in the region.

First, it seems that the time is ripe for a careful evaluation of past state and local development practices which offer a variety of financial inducements to industry with much of the activity centered on manufacturing employment. Once more prevalent in the South, this type of activity, especially industrial revenue bond financing, has spread rapidly to other states since 1966 (Miller). This increased competition would seem to imply reduced effectiveness of a group of policies whose effectiveness was already in doubt. This is however, a regional perspective, and the prospect of ending any type of incentive program may be attractive at the state level only with some assurance that other states in the region will take the same action. Achieving the regional cooperation necessary to evaluate programs which are costly to the states but of questionable regional impact would seem a worthwhile goal of policy makers, although an extremely difficult one.

Another area of emphasis for public policy in the Southern region is the formation of human capital. As noted above, the South faces increasing competition from other states in its search for manufacturing employment. Further, as Hansen notes, the South faces increasing competition from foreign countries for low-wage industry and from other states like California for the newer high-wage or high technology industry. The brief review of data here also suggests that the manufacturing states of the South face stiff competition from within the region in the high technology area, namely Florida and Texas. As noted, these two states captured over 40 percent of new manufacturing employment in the South over the 1969-1981 period.

Competition for jobs in this new arena would seem to require a substantial and sustained commitment to investment in human capital. Hansen also warns against wholesale efforts to create "... research and educational magnets on the model of Stanford-Berkeley and Harvard MIT" (p. 10). Again, the success of such efforts are long run and require commitments in all aspects of human capital formation and at all levels of the educational process. To be sure the South has made great progress in these areas, but deficiencies remain, and as Hansen concludes "... the future of the South will be tied to its success in addressing these deficiencies" (p. 11). This conclusion appears particularly relevant for the manufacturing states where transition and structural change appear to be a reality.

\section{Concluding Comments}

In conclusion the South has been successful from the standpoint of economic development. Both population and employment have increased faster than national averages. Further, the line of reasoning here does not suggest any imminent collapse or decline in the region. However, it is suggested that past Southern performance in the growth of manufacturing industry cannot continue indefinitely. Thus, particularly for those states with high concentrations of employment in manufacturing, the need for a 
new development strategy seems a reality. Such a strategy should be based on a detailed state-by-state and regional assessment of past growth and future prospects. Two areas suggested for emphasis are a review of current development incentive programs and continued improvements in the human capital of the region.

\section{REFERENCES}

James W. Clay and Alfred W. Stuart, "Uneven Growth: Southern Population Change at the County Level," Economic Review, June 1982, pp. 43-49.

James S. Fisher and Dean M. Hanink, "Business Climate: Behind the Geographic Shift of American Manufacturing," Economic Review, June 1982, pp. 20-30.

Niles Hansen, "The New International Division of Labor and Manufacturing Decentralization in the United States," The Review of Regional Studies, Vol. 9, No. 1, Spring 1979, pp. 1-11.

Charles R. Hulten and Robert M. Schwab, "Regional Productivity Growth in U.S. Manufacturing: 1951-78," The American Economic Review, Vol. 74, No. 1, March 1984, pp. 152-162.

James P. Miller, Interstate Competition for Business: Changing Roles of Federal and State Initiatives, United States Department of Agriculture, ERS Staff Report, AGES 831012.

David Mulkey and B.L. Dillman, "Location Effects of State and Local Industrial Development Subsidies," Growth and Change, Vol. 7, No. 2, pp. 37-43.

Monroe Newman, "U.S. Regionalism: Evolution of an Era," The Review of Regional Studies, Vol. 7, No. 1, Spring 1977 , pp. 1-10.

Harry W. Richardson, "The State of Regional Economics: A Survey Article," International Regional Science Review, Vol. 3, No. 1, Fall 1978, pp. 1-48. 